\title{
Development of Instructional Design Based on Computer Assisted Instruction Models for Database System Course in Information Technology Colleges
}

\author{
Ruliah $^{1,2, *}$, Suyitno Muslim ${ }^{1}$, Zulfiati Syahrial ${ }^{1}$, Andita Suci Pratiwi ${ }^{3}$ \\ ${ }^{1}$ Department of Educational Technology, Universitas Negeri Jakarta, Indonesia \\ ${ }^{2}$ Department of Information System, STMIK Banjarbaru, Indonesia \\ ${ }^{3}$ Department of Informatics Engineering, STMIK Banjarbaru, Indonesia
}

Received December 10, 2019; Revised June 20, 2020; Accepted July 29, 2020

\section{Cite This Paper in the following Citation Styles}

(a): [1] Ruliah, Suyitno Muslim, Zulfiati Syahrial, Andita Suci Pratiwi , "Development of Instructional Design Based on Computer Assisted Instruction Models for Database System Course in Information Technology Colleges," Universal Journal of Educational Research, Vol.8, No. 9A, pp. 21 - 30, 2020. DOI: 10.13189/ujer.2020.082004.

(b): Ruliah, Suyitno Muslim, Zulfiati Syahrial, Andita Suci Pratiwi (2020). Development of Instructional Design Based on Computer Assisted Instruction Models for Database System Course in Information Technology Colleges. Universal Journal of Educational Research, 8(9A), 21 - 30. DOI: 10.13189/ujer.2020.082004.

Copyright $\bigcirc 2020$ by authors, all rights reserved. Authors agree that this article remains permanently open access under the terms of the Creative Commons Attribution License 4.0 International License

\begin{abstract}
Learning systems based on traditional face-to-face approaches that are teacher-centered, often result in teachers not completing delivering teaching material due to time constraints. This has an impact on the unachieved learning goals that have been set. Instructional design plans that do not support the learning process are carried out effectively, exacerbating this situation. This paper proposes an instructional design model that integrates a Computer Assisted Instruction (CAI) model based on a combination of Tutorial models and Drill and Practice models, to support the learning of Database Systems in information technology colleges in Indonesia. Unlike the interactive CAI model which is generally desktop based, this paper proposes a CAI model with a web-based interactive learning system and is connected to external learning resources. These external learning resources provide resources relevant to the theme of learning to enrich students' insights in developing learning concepts, so that they truly become an effective medium for independent learning, anytime and anywhere outside of formal learning time. This research uses the Research and Development (R\&D) method, consisting of three main stages: system requirements analysis, system development, and formative evaluation. Formative evaluation involves expert validation, one-on-one student evaluations, and field trials to test the effectiveness of instructional designs.
\end{abstract}

Instructional design development refers to the basic model developed by Dick and Carey, but modified in the Learning Strategies section. The average value of the results of the validation of experts (media experts, instructional design experts, and content experts) to the instructional design products developed reached $82.6 \%$. This value indicates the instructional design product in the appropriate and effective categories of use. Student responses to students' one-on-one evaluations and field trials show that instructional design products developed are appropriate for students to use to learn independently and be actively involved in the learning process, with average grades (attractive appearance, friendly use, and presentation material) reached $84.2 \%$, while the average level of mastery of students in certain areas of competence reached more than $95 \%$.

Keywords Instructional Design, Computer Assisted Instruction, Tutorial Model, Drill and Practice Model, Formative Evaluation

\section{Introduction}

Management Information System (MIS) is a 
computer-based system consisting of databases, software, procedures, people and other devices that are used to produce supporting information for an organization's decision making effectively and efficiently. MIS is used as a source of relevant information, supporting the activities of stakeholders and customers of an organization (Susanto, 2012). The reliability of an organization obtains a competitive advantage is determined by how the information system is managed and used properly within the organization, so as to improve services and reduce operational costs (Ramayah \& Omar, 2010). Good management of information systems can also increase company productivity (Oliveira \& Martins, 2011), improve team performance (Oliveira \& Martins, 2010), and make management easier to make effective decisions (Rabren, 2010).

An important part of an Information System design, is the Database System. The database becomes a major strategic component for Information Systems to support management decision-making (Piattini \& Diaz (2000). The database system provides the function of searching, retrieving and displaying data content (Xu, Yamazaki, \& Villars, 2011). The database system provides a means of access that is flexible, protects data from damage, and avoids illegal use (Stallings, 2011). Database systems provide a means for shared use such as: data connectivity to minimize data duplication, maintain data integrity, and eliminate data dependency on application programs. Database systems also standardize the definition of data elements (Elmasri \& Navathe, 2016).

The design of an effective database system is the key to the success of information systems (Raharjo, 2012). An effective database system design makes it easy to reuse data contained in a database system, thereby increasing the quality of the information system. When an organization needs a new application, while at the same time the database system design is well available, the system developer (programmer) only needs to create the interface needed by the user to connect to the available database system. In order to run well, the database system design must be well prepared so that it can support the development of the system in the future. Therefore, it is very important to provide a good database system design to support data access requests for other users or systems. Knowledge of database systems is absolutely needed by everyone who wants to take part in the field of information systems technology development.

One area of study in computer science is the database system. The Joint Task Force on Computing Curricula Association for Computing Machinery (ACM) and the IEEE Computer Society in 2013 placed the Database System as one of the fields of study in the Undergraduate Degree Programs in Computer Science (IEEE Computer Society, 2013). The Australian National University using the ACM-IEEE Computer Science Curriculum in 2015 also places the database system as one of the fields of study
(Milthorpe, 2017). Schildkamp, Lai, \& Earl (2013) suggested that the database system received a lot of attention in the field of education, especially in the Computer Science program.

The results of preliminary research that we did at the Department of Information Systems STMIK Banjarbaru (one of the Higher Education in Information Technology in Indonesia) showed that the Database System instructors at these tertiary institutions made instructional designs according to their individual desires without referring to design development approach model instructional programs that have been recommended by researchers in the field of education. The instructional design model developed was not validated for its effectiveness before it was used in teaching, and used a traditional face-to-face learning approach in the classroom. We conducted a study using a questionnaire aimed at Database System instructors and students of the class. We also make observations on ongoing classes. The results of our preliminary study found that the process of learning is passive, students' understanding is not optimal in certain competencies, and the atmosphere of learning in classrooms is boring. Some students seem to need special attention and handling when learning, but cannot be handled by the instructor because there is not enough time to do direct mentoring. This condition is in line with the findings of Simarmata et al. (2018) which states that teachers face difficulties conveying all material to conventional learning due to limited time allocation, consequently students lag behind learning, and cause students to not reach the minimum competency standards planned in the learning design.

Instructional design with a learning approach that focuses on students, causes students to be active, creative, and to focuse on exposing various problems and challenges (Idris \& Rajuddin, 2012). Student-centered learning approaches allow teachers to spend more time becoming agents of change (Zohrabi, Torabi, \& Baybourdiani, 2012), fixing problems experienced by certain students, consulting with students individually, and assisting students one by one in small groups. Utilization of learning technology can also help ease the work of teachers, help them become creative classroom managers, rather than just sharing information

Computer Assisted Instruction (CAI) is a form of computer-based learning that provides instruction, tests, and student learning feedback independently, with very little or no teacher involvement (Darmawan, 2011). CAI uses tutorial models, exercises and practices, simulations, and problems solving approaches in presenting topics as well as testing students' understanding. These programs allow students to learn the material at their own pace. CAI has been widely tested in the teaching system. Widayanti tested the use of CAI in the Operating System of Class X Vocational High School in Indonesia. The study showed students' responses to learning media by $73.75 \%$ included in both categories and student learning outcomes were on 
average 82.00 in the post-test (Widayanti \& Wibawa, 2016). Suleman, Hussain, Din and Iqbal (Suleman, Hussain, Din, \& Iqbal, 2017) tested the effects of CAI on the teaching of Physics of High School students. They found that CAI-based teaching had a significant positive effect on students' academic achievement and retention in Physics, and recommended the use of computer-assisted teaching techniques for science teachers. Previously Rahman, Ismail, and Nasir (Rahman, Abd, \& Ismail, 2014) also tested the effects of CAI on the teaching of Physics (Movement and Vector Analysis) for High School students. Their findings indicate that there is an increase in students' learning motivation and conceptual understanding of learning using interactive software media.

This paper presents an instructional design development model with an interactive CAI-based learning approach using a combination of tutorial models and drill \& practice models in learning Database Systems, case studies at the Information Systems Department of the School of Information Management and Computer BanjarbaruIndonesia.

\section{Literature Review}

Megawaty (2017) developed a software-based instructional design using the ADDIE model for Database learning in Higher Education. There is little information regarding the use of the ADDIE model in the study, and there is no information about the product validation process. Putra, Wirawan \& Sindu (Putra, Wirawan, \& Sindu, 2017) have also used the ADDIE model in developing Project-Based Learning-based Database Administration instructional designs. The Moodle-based E-Module is part of the design to support the instructional design. Expert validation, student responses, and field tests form part of the instructional design evaluation process that was developed.

Faiza (2016) developed the instructional design of Database learning media using an Android-based software system for vocational high school students in Indonesia. The instructional design was developed following the 10 steps in Research and Development proposed by Sugiyono (2015). Validation of instructional products is done by testing the feasibility of the media by media experts (media design, material, language) and student responses. This research also measures the level of students' mastery learning achievement. This study does not suggest a learning strategy for each subject in the Database System.

Several learning approaches have also been proposed in learning database systems. Demour (2010) proposes a Cognitive Training-based approach to teaching Relational Database Analysis and Design. The Cognitive Training Approach divides the stages of learning into three main phases, namely: 1) the phase of breaking down the database design process into manageable phases, where each phase has been established achievements and completion procedures; 2) The phase introduces students to the theoretical basis of each phase that is followed, by introducing practical examples related to that phase; 3) Phase grouping of students in the class and assigning a small problem to them to be solved. One of the requirements of the course is the delivery of real-life problems that represent students' understanding of the concept of the course. Students work on these projects in groups outside the classroom that have different members from those in the classroom.

Paulova, Tesarova, \& Manenova (2010) introduce a learning approach to Database Systems supported by eLearning at the Faculty of Management and Information, Hradec Kralove University. The subject of observation is the cognitive performance of students (memory, understanding and application of acquired knowledge).

Yuelan at al. (2011) propose concepts that incorporate various methods in learning database systems. The use of multimedia technology to simulate the processes and effects of database systems, can motivate students to learn so as to improve the efficiency and quality of teaching. The project-based approach based on constructivist learning theory impacts on students becoming more familiar with system operations, so students can concentrate on the main purpose of database studies without having to spend a lot of time analyzing business processes. Implement an experimental based teaching model. Combining theory with practice will help students master basic knowledge theoretically, enable students to master scientific knowledge, and foster independent learning abilities and motivate learning enthusiasm.

Mason (2013) introduces a practical approach to teaching Database Administration at Regis University College for Professional Studies (CPS). The Regis approach encourages the development of students' soft skills through role simulations in project leadership structures, such as: Project Managers, Technical Leaders, and Project Leaders. Students improve communication skills by working on software development projects in real life. Students develop and maintain databases used in undergraduate and graduate programs in CPS. The Regis approach aims to inspire students to continue to study the subject of database technology after they graduate.

Hilles (2017) proposes the "MDB" approach to Knowledge-Based Intelligent Tutoring System in teaching Database Systems, using computer-based interactive learning tutorials. The MDB was built as an education system by using the authoring tool. The MDB system observes students' actions and adapts to their knowledge and learning abilities. The MDB smart tutoring system helps students understand, build, and use databases. MDB smart guidance divides teaching materials into lessons, examples, tiered exercises, and exams.

We propose an instructional design development model that refers to the modified Dick and Carey model in the 
learning strategy section. The learning strategy uses the concept of learning based on Computer Assisted Instruction (CAI), combining the Tutorial model and the Drill \& Practice model in Database System learning. Model trials are conducted at computer-based tertiary institutions in Indonesia. The CAI model is based on a combination of Tutorial and Drill \& Practice providing conceptual understanding at the beginning of learning, then providing unstructured exercises to develop creativity and test the ability of students in the final stages of learning. This model also provides an interconnection facility to www that provides resources to enrich students' insights in developing learning concepts, so that they can truly be an effective medium for independent learning.

\section{Methodology}

We use a Research and Development (R \& D) research model that refers to Gall, Gall, \& Borg (2015) in the initial stages of the study (preliminary study), then follows the stages in the instructional design development model proposed by Dick, Carey, \& Carey (2015) as recommended by Gall and Borg. The research steps consist of:

1) Analyze Instructional needs. The instructional formulation in the form of competency requirements in the Database System instructional design was examined in a Focus Group Discussion (FGD) involving stakeholder representatives (learning designers, two people representing management of study programs at STMIK Banjarbaru colleges, 10 representatives of graduates of STMIK Banjarbaru colleges, and 10 college graduates users from various fields of business).

2) Develop instructional designs referring to the Dick \& Carey (2015) development model. The CAI concept based on a combination of Tutorial model and Drill and Practice model is implemented at the learning strategy preparation stage.
3) Product validation through formative evaluation of instructional designs. Formative evaluation consists of expert validation (Contents Exper, Media Expert, Instructional Design Expert) and one-to-one validation by students. At the end of each trial phase, data analysis and product revisions are carried out based on input obtained from each evaluation / trial phase.

4) Test the effectiveness of instructional products through fields trials. Thirty students who had the characteristics of high, medium, and low ability were respondents at the product trial stage.

\section{Results and Discussion}

\subsection{Proposed CAI-based Instructional Design Development Model}

The proposed CAI-based Database System instructional development model is presented in Figure 1. There are three main stages in the development of instructional design, namely: the stages of identifying, the stages of developing, and the stages of evaluating.

Initial Identification Stage. The identifying activities focus on the formulation of general instructional goals, instructional analysis, and analysis of learners' initial behavior. The formulation of general instructional goals is determined based on the results of studies involving students (who are still active and who have graduated), educators, and graduates, to ensure that the General Instructional Objective is obtained which reflects the needs of the three parties in the education world. Instructional analysis is done by describing general competencies into sub competencies and special competencies that are arranged logically and systematically. Analyzing the initial characteristics of students aims to determine the extent of competence, ability or knowledge, skills and attitudes that have been mastered by students so that they are eligible to participate in instructional activities that will be held. 


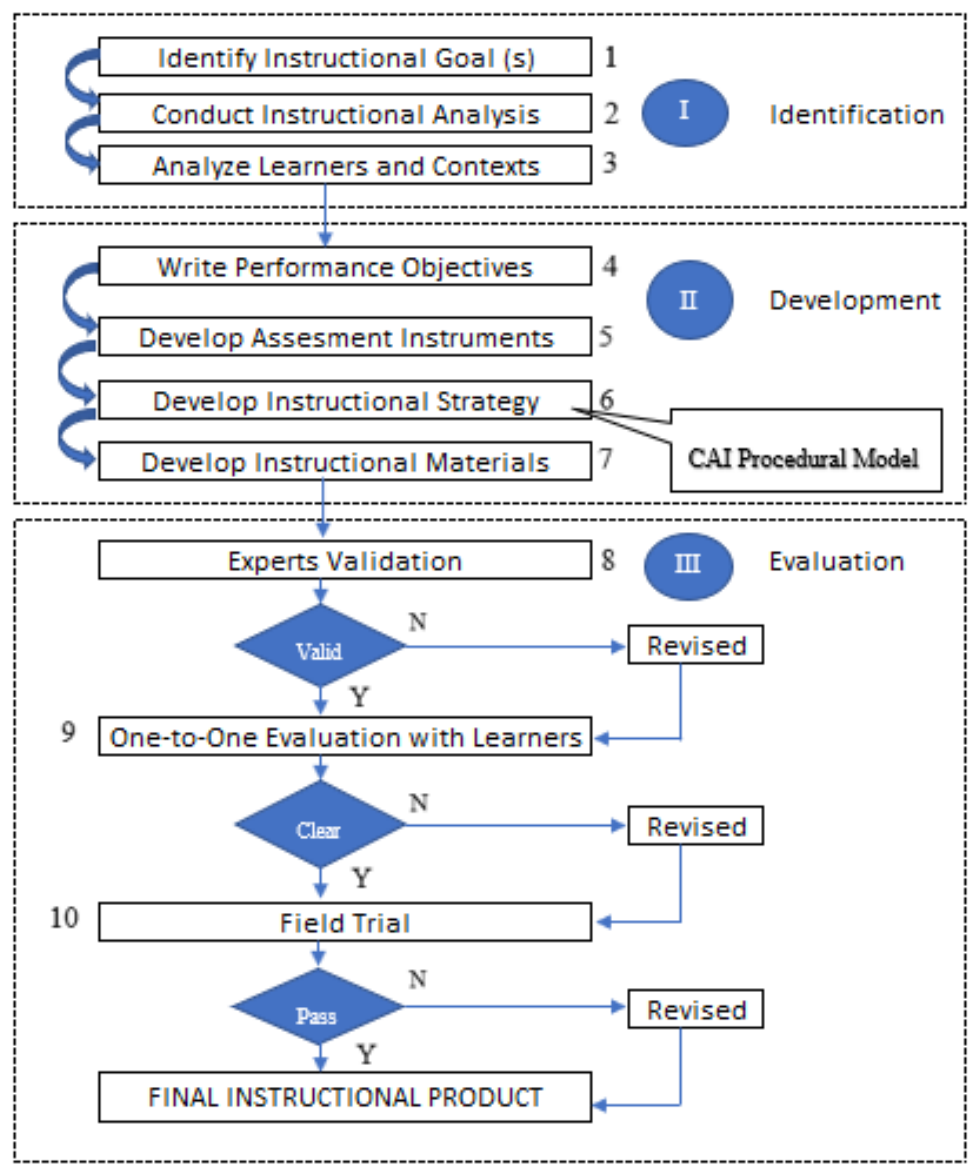

Figure 1. CAI-based Instructional Design Development Model for Database Systems

Development Stage. Development activities focus on the formulation of Special Instructional Objectives, preparation of learning outcomes assessment instruments, preparation of learning strategies, and development of instructional materials. Determination of Specific Instructional Objectives is based on the results of instructional analysis and the results of analysis of the students' initial characteristics. The initial characteristics of students are outlined in the line between behavior that does not need to be taught and behavior that must be taught to students. The behavior to be taught is then formulated in the form of Special Instructional Objectives. The specific instructional objective formulation is then used to determine the various components in the instructional system including measuring tools for learning outcomes and learning content.

Development of learning outcomes assessment instruments aimed at measuring the level of mastery of students in each competency that has been set on the Instructional Objectives. The design of the learning outcomes assessment instrument is intended to measure the area of cognitive taxonomy (knowledge), the area of psychomotor taxonomy (practice), and the affective region (attitude of behavior). Cognitive assessment of students' responses using instruments in the form of tests, both in written and oral form. Psychomotor responses of students are measured by observation tools in the form of a check list combined with an attitude scale, while a picture of the attitudes, perceptions or opinions of students, is measured using rating scales.

The design of the purchasing strategy is adjusted to the characteristics of the Database System. In generally the Database System topic is divided into two programs. The first part consists of analysis and logical design (Requirements Specialization and Requirements analysis, Data Modeling, Relational Mapping, Normalization), and the second part consists of physical design and implementation in a Data Base Management System / DBMS (SQL: Data Definition Language, SQL: Data Manipulation Language). The concept of needs analysis and requirements specification is a program that is oriented to user needs, so that the scope of the study is an unstructured problem. The design and implementation studies are adjusted to the need analysis and requirements specifications. The characteristics of such a database system require the use of learning methods that not only emphasize conceptual understanding, but need in-depth practice exploring examples of unstructured cases.

Tutorial-based CAI models such as Lestari (2015) and Seow \& Pan (2017) are learning strategies developed for 
the structure of teaching materials that have characteristics: new information, conceptual, and emphasize optimizing the achievement of cognitive aspects. The Drill models such as Pacol \& Patacsil (2017) and Pujawan (2018) provide learning experiences through the creation of imitations of experiences that approach the real atmosphere through the provision of exercises to develop creativity and test students' abilities (Darmawan, 2011). The characteristics possessed by the Tutorial model and the Drill model are in line with the learning characteristics of a database system that demands learning concepts that emphasize conceptual understanding and require in-depth training to expose unstructured cases.

Our paper proposes a CAI model based on a combination of Totorial and Drill and Practice models, which is formulated in nine steps for learning database systems:

1) Introduction Section. The CAI system displays instructions for the learning steps to be taken.

2) Present Information. The CAI system presents material sourced from local resources, which is packaged in the form of tutorial scripts. In addition to information in the form of text, the presentation of information also takes the form of visual information such as pictures, graphics, photographs and images / videos.

3) Quistion and Response. The CAI system presents questions and assesses the ability of students to remember and understand the lessons presented. This stage unites the evaluation process in the material presentation stage.

4) Feedback Response. The CAI system provides feedback as a reaction to the responses given by students. The feedback function is to inform whether the response given by students is correct or not. Feedback in the form of messages in the form of text and graphic illustrations. If the response given by students is right, the program provides reinforcement for students. However, if the student response is wrong, the program gives a sentence that the response given is wrong.

5) Judge Response and Remedial. The CAI system assesses and evaluates students' responses so that feedback can be given to students. Assessment serves to evaluate student learning outcomes and make decisions whether the learning process can be continued to the next stage or repeated. Repetition takes the form of a restatement of material students have seen, sourced from local resources.

6) Case Exercise and Response. The CAI system presents questions in the form of new case studies, but is still relevant to materials that have been studied / seen by students, as well as assessing the extent to which students' abilities to develop a particular material that has been presented. This session can be achieved by students if all the main learning material has been passed and mastered perfectly.

7) Feedback for Case Exercise. The CAI system provides feedback as a reaction to the responses given by students (as in step number 4)

8) Judge Response and Remedial for Case Exercise. The CAI system assesses and evaluates students' responses so that feedback can be given to students. Assessment serves to evaluate the results of case exercises and make a decision whether the learning process can be continued to the next stage or repeated. Repetition takes the form of presenting enrichment material sourced from online resources / internet (www, download files, you tobe, etc) to enrich students' insights before returning to doing case exercises. This concept can train students to think critically and develop insights into pre-determined material.

9) Closing. The CAI system presents a summary of information on learning outcomes. Summary of learning outcomes in the form of important points from the contents of a paragraph, learning objectives, and provides recommendations for further learning.

Steps one through five are the basic logic structure of CAI based Tutorial, while steps six through eight are CAI based Drill and Practice logic structures. The two models are integrated to produce a logical learning procedure in the form of applying the Tutorial system at the beginning of teaching to provide conceptual understanding for students, and at the end of the teaching provides exercises to develop creativity and test the ability of students. CAI applications run on a Web-based platform, but are not limited to being integrated in CMS (Content Management System) based applications such as Moodle. Instructional products are designed to help students learn independently, learn anytime and anywhere, and are also used in classroom learning with teacher assistance.

Development of instructional materials refers to instructional strategies, the students' initial characteristics, and learning outcome assessment instruments. Instructional materials developed support the blanded learning system (face-to-face instructional activities and online instructional activities). Materials for face-to-face instructional activities in the form of lecturer guides, student guides, and compilation teaching materials. For online instructional activities, teaching materials are provided in the form of digital teaching materials in the form of compilation and online learning media that are connected to the internet network.

Evaluation Stage. The evaluation model used to validate the instructional design of a database system is the Formative evaluation model. Dick and Carey (2015) divided the stages of formative evaluation into four stages, namely: one-on-one evaluations by experts, one-on-one evaluations by students, small group evaluations, and field trials. In practice Keller (in Suparman, 2015) states that not 
all steps can be carried out in formative evaluation, but based on certain considerations two or three steps can be taken. The formative test in this paper begins with expert validation (instructional design expert, Information Technology media expert, database system content expert), then one-to-one evaluation by students, and ends in field trial activities.

In the validation process by experts, each one expert for instructional design, information technology media, and database system content is asked to look for instructional designs that are developed. Input from each expert is used to perfect the instructional design before proceeding to the one-to-one evaluation stage by students.

The one-to-one evaluation by students involves three students based on characteristics such as the target population. All three students have high, medium, and low abilities. Instructional material is given to students to be studied, then their understanding about certain parts of the instructional system is asked. Learners are asked to provide comments about the material and learning activities carried out. Input from students becomes a reference for revising instructional designs before field trials are conducted.

Field trials involve 30 students who have high, medium and low abilities. The test is conducted by preparing the learning environment, facilities, and tools needed in accordance with instructional strategies and forms of instructional activities that have been determined. Instructional activities begin by holding a pretest to find out the initial competence of students. Furthermore, conducting learning activities in accordance with the CAI strategy-based Tutorial and Drill and Practice. Posttest was held after learning activities. At the end of the learning session, students are asked to provide input regarding instructional activities, as a reference to perfect the instructional design before becoming the final product. The effectiveness of instructional activities is measured by comparing the significance of the value of student learning outcomes at Posttest with Pretest, as well as the achievement of predetermined competency standards. The effectiveness of instructional activities is also measured by the attitudes of students and instructors towards instructional activities, the feasibility of instructional activities in terms of the relevance of time and cost, and the availability of other learning resources according to needs.

\subsection{Test the Effectiveness of the CAI Based Database System Instructional Design}

\subsubsection{Expert Validation}

Assessment by experts and students on instructional design products is carried out using a questionnaire adapted from 'Selection and Evaluation of Learning Tools: 2008 Guidelines'. The rating range is 1-4 with interpretations $4=$ exact, 3 = quite right, 2 = inaccurate, and $1=$ incorrect. Each given value is transformed into a percentage with a description of values $85-100=$ very feasible does not need to be revised, $75-84=$ worth does not need to be revised, $55-74=$ not enough to be revised, and $0-54=$ not worthy of needing revision. In the questionnaire, experts can provide suggestions, criticisms, and input on the learning media products developed.

Instrument points for evaluating instructional design are related to aspects of the accuracy of the Learning Objectives Formulation, Evaluation Tools, Learning Strategies, and learning materials. To evaluate Learning Materials / content, items of instruments related to aspects of the relevance of learning materials and quality of learning materials, while for Evaluation of Learning Media CAI uses items of instruments relating to aspects of user friendly (application appearance, functional features, and effectiveness of use). Table 1 presents the results of one-on-one evaluations by experts on the instructional design products developed.

Table 1 presents the results of the content expert assessment averaging $82.50 \%$, showing that the learning content in the category is feasible to use. The results of the instructional design expert assessment reached an average of $80.50 \%$, indicating the instructional design was in the feasible and effective category of use. Likewise, the results of the Information Technology expert's assessment reached $84.75 \%$, indicating that the learning media of the online technology-based Database System is also feasible to use. Overall, the average value of the results of the experts' validation of the Database System instructional design products developed reached $82.60 \%$, indicating that the products in the appropriate and effective categories were used in learning.

\subsubsection{Student One-to-One Evaluation and Field Trials}

Testing the effectiveness of the development of an instructional database system design is done by comparing the significance of the learning outcomes of students in the Posttest with the Pretest (achievement of predetermined competency standards) when field testing. The effectiveness of instructional design development was also confirmed to students through one-on-one student test. In the one-on-one test of students, students are asked to provide responses / responses related to aspects of user friendly (appearance, effectiveness of use) and aspects of material presentation. Students' responses are also asked at the end of the field test. Evaluation results as presented in table 2. 
Table 1. Expert Validation Results

\begin{tabular}{ccll}
\hline Expert & $\begin{array}{c}\text { Average Value } \\
(\mathbf{\%})\end{array}$ & \multicolumn{1}{c}{ Examples of Expert Feedback and Input } \\
\hline $\begin{array}{c}\text { Database System Content } \\
\text { Expert }\end{array}$ & 82.50 & & $\begin{array}{l}\text { Updates of material in some sub-topics need additional interviewIlustrasi } \\
\text { dalam bentuk gambar/vidio belum cukup relevan }\end{array}$ \\
$\begin{array}{c}\text { Instructional Design Expert } \\
\text { Information Technology } \\
\text { Expert }\end{array}$ & 80.50 & - & $\begin{array}{l}\text { Learning materials need to be equipped with adequate case examples } \\
\text { Some evaluation items are not relevant to Learning Objectives }\end{array}$ \\
\hline Average & 84.75 & - & \begin{tabular}{l} 
Online media is not responsive enough \\
\hline
\end{tabular} \\
\hline
\end{tabular}

Table 2. Student Evaluation Results and Field Test

\begin{tabular}{|c|c|c|c|}
\hline $\begin{array}{c}\text { Pretest } \\
\text { Completeness } \\
\text { Average (\%) } \\
\end{array}$ & $\begin{array}{c}\text { Posttest } \\
\text { Completeness } \\
\text { Average (\%) } \\
\end{array}$ & $\begin{array}{c}\text { Instructional Product } \\
\text { Assessment Results } \\
(\%) \\
\end{array}$ & Examples of Student Response and Input \\
\hline \multirow[t]{3}{*}{54.60} & 95.20 & $\begin{array}{l}\text { Attractive } \\
\text { Disply: } 86.50\end{array}$ & $\begin{array}{ll}\text { - } & \text { Illustrations in the form of pictures / videos need to be } \\
\text { presented more interestingly } \\
\text { - } & \text { Consistency Fill Forms } \\
\text { - } & \text { Image resolution is still low }\end{array}$ \\
\hline & & $\begin{array}{l}\text { User } \\
\text { Frienly: } 84.50\end{array}$ & - The formulation of work instructions is not yet clear enough \\
\hline & & $\begin{array}{l}\text { Material Presentation: } \\
81,60 \\
\text { Average: } 84.20\end{array}$ & $\begin{array}{l}\text { - Some paragraphs have unclear sentence meanings } \\
\text { - } \quad \text { Need to be equipped with adequate case examples } \\
\text { final stages of learning } \\
\text { Presentation of material exceeds the planned time in the } \\
\text { learning design }\end{array}$ \\
\hline
\end{tabular}

The next Step, we describe some important findings from the results of the field test, as follows:

1) learners' perceptions of instructional design products: The results of the assessment on the aspect of attractive display reached an average of $86.50 \%$, indicating instructional design is very feasible to use. The User Friendly aspect reached an average of $84.50 \%$, indicating an instructional design worth using. As for the Material Presentation aspect, the assessment results reached an average of $81.6 \%$ indicating the instructional design was appropriate to use. Overall, the average value of students' perceptions of students' perception of the product design of the Database System that was developed reached an average of $84.20 \%$, indicating that instructional design products in the appropriate category were used.

2) Impact of the application of instructional design products: $85 \%$ of 30 respondents stated that the learning scenario and training model offered in the instructional strategy using the CAI model that combines Tutorial and Drill \& Practice approaches greatly motivates students in learning and training, so that the target of learning achievement can be achieved. This statement is supported by the percentage of mastery learning in one particular area of competency tested, which is, on average, greater than $95 \%$. This finding is consistent with the findings of Thomas, et al. (2013) and Suleman et al. (2017) which concluded that CAI-based learning can motivate and improve student achievement.

3) The other side of the test findings is that students feel that one session of the meeting cycle in the classroom using CAI-based instructional design is too long. Completion of one teaching session exceeds the time specified in the instructional design, even though the learning material has been simplified. Students propose the CAI model is only used in learning sessions outside the classroom, with sufficient time available for one learning session. This finding is identical with the findings of Chaudhari (2013) that CAI is merely an additional instructional strategy in effective teaching.

\section{Conclusions and Recommendations}

CAI-based instructional design that combines the Tutorial model and the Drill and Practice model, can motivate students to learn Database Systems independently. The availability of online-based technology now makes it possible to develop interactive CAI-based instructional designs that are connected to external learning resources that provide a variety of resources relevant to the theme of learning, to enrich students' insights in developing learning concepts. The results of the expert validation of the 
instructional design developed, showed that the interactive CAI-based instructional design products using online technology, feasible and effectively used in learning.

Although scenarios in interactive CAI-based instructional design can motivate students to learn independently, further discussion is still needed in relation to other findings in this study. Another meeting showed that there were students who were indicated to have difficulty following certain sessions in learning Database Systems, especially those related to system modeling material. Students state that they still need an instructor (companion) to get a deeper explanation when they have difficulty understanding certain parts of the learning material. On this basis, the interactive CAI features connected to the online system (website) still need to be developed, especially regarding how the interconnecting model of the interactive CAI system based on Tutorial and Drill with a Web-based system to connect students with instructors interactively, to enable students to more easily interact with teacher when students have difficulty learning independently. This is part of the limitations of the research recommended for further study.

Another limitation of this research is that a partial study has not been conducted to find out which component between the two components that makes up the instructional system (CAI-based Instructional Design model; Model Tutorial - Drill and Practice) which gives a better impact in the application of instructional design. This is important to be discussed further in future studies, to provide the right type of intervention for the two components that make up the instructional design system, if under certain conditions the results of implementing the instructional system do not have an effective impact.

\section{REFERENCES}

[1] Chaudhari, P. (2013). Computer Assisted Instruction (CAI): Development of instructional Strategy for Biology Teaching. UGC-JRF, 2(1), 106-116

[2] Choi, S. Y., Lee, H., \& Yoo, Y. (2010). The Impact of Information Technology and Transactive Memory Systems on Knowledge Sharing, Application, and Team Performance: A Field Study. MIS quarterly, 34(4), 855-870.

[3] Darmawan, D. (2011). Teknologi Pembelajaran. Bandung: Rosada Karya.

[4] Dick, W., Carey, L., Carey, J.O. (2015) The Systematic Design of Instruction, Eigh Edition. USA: Pearson.

[5] Dmour, A. A. (2010). Propose A Cognitive Apprenticeship Approach for Teaching an Analysis \& Design Database Relational Course. Journal of Information \& Computational Science, 7(12), 2495-2502.

[6] Elmasri, E., \& Navathe, S.B. (2016). Database Sistem, Seventh Edition, USA: Pearson.
[7] Faiza, H. Z. (2016). Pengembangan Media Pembelajaran Basis Data Berbasis Android Untuk Kelas XI di SMK Negeri 2 Surabaya. IT-EDU, 1(01), 9-13.

[8] Gall, M.D., Gall, J.P., Borg, W.R. (2015). Applying Educational Research, Seventh Edition. USA: Pearson.

[9] Hilles, M. M., \& Naser, S. S. A. (2017). Knowledge-based Intelligent Tutoring System for Teaching Mongo Database. European Academic Research, 4(10), 8783-8794

[10] Idris, A., \& Rajuddin, M. (2012). The Trend of engineering education in Nigerian tertiary institutions of learning towards achieving technological development. Procedia-Social and Behavioral Sciences, 56, 730-736.

[11] IEEE Computer Society. (2013, December). Computer Science Curricula 2013: Curriculum Guidelines for Undergraduate Degree Programs in Computer SCience, The joint Task Force on Computing Curricula, Association for Computing Machinery.

[12] Lestari, A.S. (2015). Application of Computer Based Learning Model Tutorial as Medium of Learning. American Journal of Educational Research, 3(6), 702-706.

[13] Longmuir, K. J. (2014). Interactive computer-assisted instruction in acid-base physiology for mobile computer platforms. Advances in physiology education, 38(1), 34-41.

[14] Mason, R. A (2013, July). Database Practicum for Teaching Database Administration and Software Development at Regis University. In Proceedings of the Informing Science and Information Technology Education Conference, 159-168.

[15] Megawaty, M. (2017, February). Pengembangan Metode Ajar dengan Perangkat Lunak Ajar (Studi Kasus: Mata Kuliah Basis Data). SEMNASINOTEK, 1-6

[16] Milthorpe, J. (2017). ACM-IEEE Computer Science Curriculum 2015 Structured, Australian National University. https://cs.anu.edu.au/courses/comp1110/ acmcc/, accessed 10-4-2019

[17] Oliveira, T., \& Martins, M. F. (2011). Literature Review of Information Technology Adoption Models at Firm Level. Electronic Journal of Information Systems Evaluation, 14(1), $110-121$.

[18] Pacol, C. A., \& Patacsil, F. (2017). Drill and practice courseware in its fundamentals. PSU Journal of Engineering, Technology and Computing Sciences, 1(1), 33-47.

[19] Piattini, M.G., \& Diaz, O. (2000). Advanced Database Technology and Design, Boston: Artech House.

[20] Poulová, P., Tesarova, B., \& Maneonova, M. (2010, July). Efficiency comparison of eLearning supported instruction to traditional university courses in the subject of database systems 2. In EDUCATION'10 Proceedings of the 7th WSEAS international conference on Engineering education, 157-162.

[21] Pujawan, K. A. H. (2018). The Development of Interactive Multimedia with Drill and Practice Model on Multimedia Ii (Two Dimention Animation) Course in Politeknik Ganesha Guru. Journal of Education Research and Evaluation, 2(1), 22-27.

[22] Putra, P. P., Wirawan, I. M. A., \& Sindu, I. G. P. (2017). 
Pengembangan E-Modul Berbasis Project Based Learning Pada Mata Pelajaran Administrasi Basis Data Kelas Xii Rekayasa Perangkat Lunak Di Smk Negeri 2 Tabanan. Jurnal Pendidikan Teknologi dan Kejuruan, 14(1), 60-71

[23] Rabren, J. (2010). Technology, Integration and Data Drive Supply Chain Visibility. Material Handling Management, Retrieved Business Source Complete database, 65(3), 42.

[24] Raharjo, S. (2012, November). Constraint Basis Data Sebagai Fondasi Yang Kuat Dalam Pengembangan Sistem Informasi. In Seminar Nasional Aplikasi Sains \& Teknologi (SNAST), Yogyakarta, November, 08-1 - 08-5.

[25] Rahman, M., Abd, J., \& Ismail, M. (2014). Development and Evaluation of the Effectiveness of Computer-Assisted Physics Instruction. International Education Studies, 7(13), 14-22.

[26] Ramayah, T., \& Omar, R. (2010). Information Exchange and Supply Chain Performan-ce. International Journal of Information Technology \& Decision Making, 9(01), 35-52.

[27] Schildkamp, K., Lai, M.K., \& Earl, L. (2013). Data Based, Decision Making in Education, Challenges and Opportunities. New York: Springer

[28] Seow, P. S., Pan, G. (2017). Using an online tutorial to teach REA data modeling in Accounting Information Systems courses. AIS Educator Journal, 12(1), 1-19.

[29] Simarmata, J., Limbong, T., Napitupulu, E., Sriadhi, S., Tambunan, A. R. S., \& Sinaga, E. K. (2018). Learning Application of Multimedia-Based-Computer Network Using Computer Assisted Instruction Method. Int. J. Eng. Technol, 7(2.13), 341-344.

[30] Stallings, W. (2011). Cryptography and Network Security Principles and Practice. United States of America: Prentice Hall
[31] Sugiyono (2015). Metode Penelitian Pendidikan: Pendekatan Kuantitatif, Kualitatif, dan $R \& D$. Bandung: Alfabeta.

[32] Suleman, Q., Hussain, I., Din, M. N. U., \& Iqbal, K. (2017). Effects of Computer-Assisted Instruction (CAI) on Students' Academic Achievement in Physics at Secondary Level. Computer Engineering and Intelligent Systems, 8(7), 9-17.

[33] Suparman, M.A. (2015). Desain Instruksional Modern, Jakarta: Erlangga.

[34] Susanto, A. (2012). Pengembangan Model Sistem Informasi Manajemen Pendidikan pada Program Studi Magister Manajemen Pendidikan Pascasarjana Universitas Negeri Jakarta. Jurnal of Manajemen Pendidikan, 3(1), 489-496

[35] Thomas, T., Alexander, K., Jackson, R., \& Abrami, P. C. (2013). The differential effects of interactive versus didactic pedagogy using computer-assisted instruction. Journal of Educational Computing Research, 49(4), 403-436.

[36] Widayanti, I., \& Wibawa, S. C. (2016). Pengembangan Model Pembelajaran Computer Assisted Instruction (CAI) Tipe Tutorial Dengan Aplikasi Lectora Inspire Pada Mata Pelajaran Sistem Operasi Kelas X SMK. Jurnal IT-Edu, 1(2), 65-69

[37] Xu, Y., Yamazaki, M., \& Villars, P. (2011). Inorganic materials database for exploring the nature of material. Japanese Journal of Applied Physics, 50(11S), 11RH02-1 11RH02-5

[38] Yuelan, L., Yiwei, L., Yuyan, H., \& Yuefan, L. (2011). Study on Teaching Methods of Database Application Courses. Procedia Engineering, 15, 5425-5428.

[39] Zohrabi, M., Torabi, M. A., \& Baybourdiani, P. (2012). Teacher-centered and/or student-centered learning: English language in Iran. English Language and Literature Studies, 2(3), $18-30$ 